\title{
Combination of Red Coconut Coir (Cocos nucifera $L$. var rubescens) and Linezolid on Methicillin-Resistant Staphylococcus aureus in vitro Growth
}

\author{
Trisnawati $^{1}$, Wiwin Retnowati ${ }^{2}$, Danti Nur Indiastuti ${ }^{3 *}$ \\ ${ }^{1}$ Faculty of Medicine, Universitas Airlangga, Surabaya, Indonesia \\ ${ }^{2}$ Department of Microbiology, Faculty of Medicine, Universitas Airlangga, Surabaya, Indonesia \\ ${ }^{3}$ Department of Pharmacology, Faculty of Medicine, Universitas Airlangga, Surabaya, Indonesia
}

\section{A R T I C L E I N F O}

\section{Article history:}

Received 13 May 2020

Received in revised form 09 June 2020

Accepted 11 June 2020

Available online 30 June 2020

\section{Keywords:}

Methicillin-Resistant

Staphylococcus aureus,

Cocos nucifera L. var rubescens,

well-diffusion test,

antibacterial resistance.

*) Corresponding author:

dantinurindiastuti@gmail.com

\begin{abstract}
A B S T R A C T
Introduction: Methicillin-Resistant Staphylococcus aureus (MRSA) bacterial infections may cause poor manifestations and even increase patients' morbidity and mortality. The use of antibiotics in the management of infections remains the main therapy. However, ever-increasing antibacterial resistance has prompted researchers to find the solution. This study aimed to determine the effect of a combination of red coconut coir (Cocos nucifera L. var rubescens) in various concentrations and linezolid $10 \mu / \mathrm{ml}$ on the growth of MRSA bacteria in vitro.

Methods: The antibacterial activity test method was well-diffusion test. Bacteria was plated in mueller hinton agar for 24 hours at $37^{\circ} \mathrm{C}$. The treatment groups were red coconut coir extract and its combination with linezolid $10 \mu \mathrm{g} / \mathrm{ml}$. The well-diffusion test results were statistically analyzed with the One-Way ANOVA and Tukey HSD post-hoc tests.

Results: Mean inhibitory zone diameter formed in the C. nucifera L. var rubescens extract test in various concentrations was $12.5 \pm 0.36-16.2 \pm 0.79 \mathrm{~mm}$, while its combination with $10 \mu \mathrm{g} / \mathrm{ml}$ linezolid produced mean inhibitory zone of $15.1 \pm 1.31-18.4 \pm 0.46 \mathrm{~mm}$. There was a significant difference between groups $(\mathrm{p}<0.05)$.

Conclusion: Increasing concentration of C. nucifera L. var rubescens extract was in line with the increase of mean diameter of the inhibitory zone. Extract and antibiotic combination tests showed higher mean diameter zones than the single test of materials. The combination of extract and linezolid has the potential to synergistically prevent antibacterial resistance.
\end{abstract}

\section{Introduction}

Methicillin-Resistant Staphylococcus aureus (MRSA) is a strain of $S$. aureus that resistant to penicillin and its derivatives. This bacterium was first discovered in $1961 .{ }^{1}$ In general, MRSA causes nosocomial infections. ${ }^{2}$ Another study even suggested that community-acquired MRSA infection has now become a global problem. ${ }^{3}$ Until now, antibiotic therapy is still the main therapy in cases of infection due to bacteria so that antibacterial resistance is very likely to occur. According to WHO, antibacterial resistance can occur naturally and is accelerated by improper use in humans and animals. ${ }^{4}$ Related research in Indonesia conducted in 2014 revealed the incidence of antibacterial resistance around 700,000 cases per year. ${ }^{5}$ Researchers are trying to overcome this problem with new types of antibiotics as well as by combining antibiotics and plant extracts.
Linezolid, a new type of antibiotic, has successfully overcome gram-positive infections in the last 10 years. The linezolid target is different from the previous antibiotic, which is in the $50 \mathrm{~S}$ ribosome. ${ }^{2}$ It also in different mechanism from coconut coir (Cocos nucifera L.) extract which has a target of action on cell walls. Researches stated that coconut coir can prevent the formation of biofilm, ${ }^{6}$ growth of gram bacteria, ${ }^{7}$ even MRSA with Minimum Inhibitory Concentration (MIC) of $156 \mu \mathrm{g} / \mathrm{ml}{ }^{8}$ It is because the extract contains phenol compounds that may cause intracellular leakage and inhibit the formation of peptidoglycan. ${ }^{9,10}$ Phenolic compound is secondary metabolite of plant which has the role as pathogen protector and plant's self-defense. ${ }^{11}$ Indonesia has various species and subspecies of coconut and also known as the biggest coconut producer in the world in $2014 .{ }^{12}$ This study used extracts of red coconut coir (C. nucifera L. var rubescens) 
because red coconut plant has the best resistance to pest attacks compared to other subspecies. ${ }^{13}$

The combination of antibiotics and plant extracts has not been much studied. However, a related study states that the differences in the targets of the two agents have the potential to have a synergistic effect in inhibiting bacterial growth. ${ }^{14}$ Combination of both substance are suspected can increase the spectrum of antibacterial activity, decrease toxicity, reach the antibacterial synergism, and prevent antibacterial resistance. ${ }^{15}$

\section{Methods}

This study was an experimental laboratory study using well-diffusion test. The material of $C$. nucifera $L$. var rubescens was obtained from Lumajang, East Java, Indonesia. Extraction was processed by maceration using $60 \%$ ethanol solvent. This experiment used 0.5 McFarland of MRSA from Microbiology Laboratory, Faculty of Medicine, Universitas Airlangga. The wells of $8 \mathrm{~mm}$ diameter were punched into the agar medium and filled with $100 \mu \mathrm{l}$ of either plant extract, or combination of antibiotic and plant extract. The first 4 treatment groups contained single extracts of various concentrations (50 mg/ $\mathrm{ml}, 100 \mathrm{mg} / \mathrm{ml}, 150 \mathrm{mg} / \mathrm{ml}, 200 \mathrm{mg} / \mathrm{ml}$ ), and the other 4 treatment groups contained combination of $C$. nucifera $L$. var rubescens extract and $10 \mu \mathrm{g} / \mathrm{ml}$ linezolid. Linezolid $10 \mu \mathrm{g} / \mathrm{ml}$ served as positive control and distilled water as negative control. All groups were incubated at $37^{\circ} \mathrm{C}$ for 24 hours. Inhibitory zone measurement $(\mathrm{mm})$ was performed using calipers. Inhibitory zones obtained were processed statistically using IBM SPSS ver. 25 by one-way ANOVA with $\mathrm{p}<0.05$ considered as significant. This study has received ethical eligibility by the Health Research Ethics Committee, Faculty of Medicine, Universitas Airlangga, Surabaya, Indonesia.
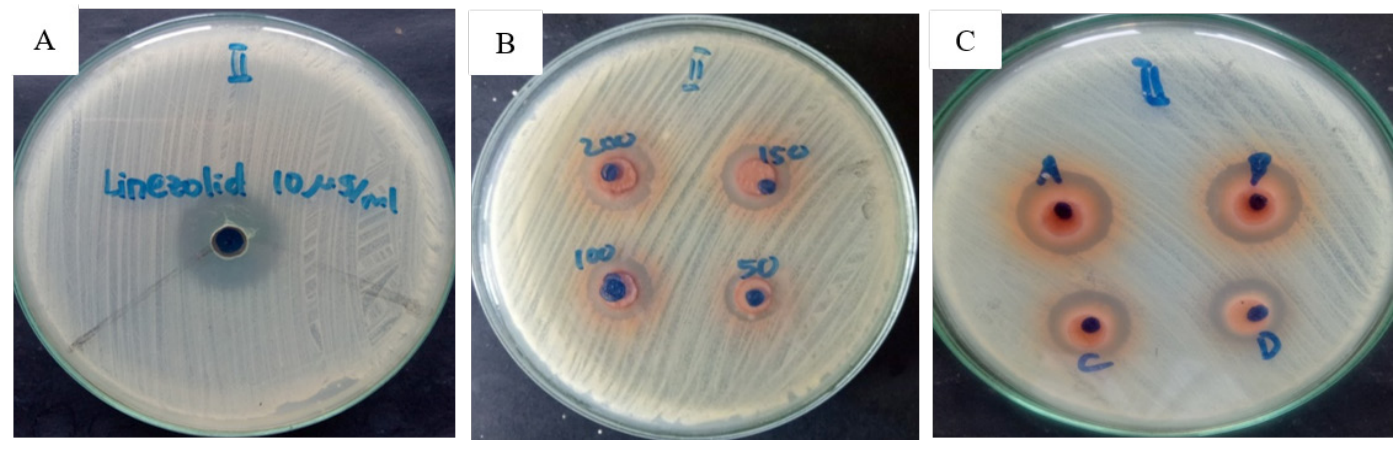

Figure 1. Well diffusion method of (A) Linezolid $10 \mu \mathrm{g} / \mathrm{ml}$ as positive control, (B) Cocos nucifera L. var rubescens extract in many concentration $(50 \mathrm{mg} / \mathrm{ml}, 100 \mathrm{mg} / \mathrm{ml}, 150 \mathrm{mg} / \mathrm{ml}, 200 \mathrm{mg} / \mathrm{ml}),(\mathrm{C})$ combination of each concentration of Cocos nucifera $L$. var rubescens extract with linezolid $10 \mu \mathrm{g} / \mathrm{ml}$ *

*Left upper: $200 \mathrm{mg}$, right upper: $150 \mathrm{mg}$, left lower: $100 \mathrm{mg}$, right lower: $50 \mathrm{mg}$

Table 1. The mean of inhibition zone and the result of One-Way ANOVA test

\begin{tabular}{|c|c|c|c|c|c|}
\hline Group & $\mathbf{n}$ & Concentration & $\begin{array}{l}\text { Mean of Inhibition } \\
\text { Zone (mm) }\end{array}$ & $\mathbf{p}$ & $\begin{array}{l}\text { p (One-Way } \\
\text { ANOVA test) }\end{array}$ \\
\hline Linezolid $10 \mu \mathrm{g} / \mathrm{ml}$ (positive control) & 4 & $10 \mu \mathrm{g} / \mathrm{ml}$ & $14.8 \pm 0.55$ & 0.384 & \multirow{10}{*}{0.000} \\
\hline Aquades (negative control) & 4 & - & 0 & . & \\
\hline \multirow{4}{*}{$\begin{array}{l}\text { Single use extract of } C \text {. nucifera } L \text {. var } \\
\text { rubescens }\end{array}$} & 4 & $50 \mathrm{mg} / \mathrm{ml}$ & $12.5 \pm 0.36$ & 0.650 & \\
\hline & & $100 \mathrm{mg} / \mathrm{ml}$ & $13.9 \pm 0.27$ & 0.240 & \\
\hline & & $150 \mathrm{mg} / \mathrm{ml}$ & $15.0 \pm 0.38$ & 0.074 & \\
\hline & & $200 \mathrm{mg} / \mathrm{ml}$ & $16.2 \pm 0.79$ & 0.246 & \\
\hline \multirow{4}{*}{$\begin{array}{l}\text { Combination extract of C. nucifera } L \text {. } \\
\text { var rubescens and linezolid } 10 \mu \mathrm{g} / \mathrm{ml}\end{array}$} & \multirow{4}{*}{4} & $50 \mathrm{mg} / \mathrm{ml}$ & $15.1 \pm 1.31$ & 0.225 & \\
\hline & & $100 \mathrm{mg} / \mathrm{ml}$ & $16.8 \pm 1.31$ & 0.613 & \\
\hline & & $150 \mathrm{mg} / \mathrm{ml}$ & $17.6 \pm 0.99$ & 0.861 & \\
\hline & & $200 \mathrm{mg} / \mathrm{ml}$ & $18.4 \pm 0.46$ & 0.666 & \\
\hline
\end{tabular}


Table 2. The result of Tukey HSD post-hoc test

\begin{tabular}{lcc}
\multicolumn{1}{c}{ Group } & $\mathrm{n}$ & Subset \\
\hline \hline Extract $50 \mathrm{mg} / \mathrm{ml}$ & 4 & $\mathrm{a}$ \\
\hline Extract $100 \mathrm{mg} / \mathrm{ml}$ & 4 & $\mathrm{ab}$ \\
\hline Linezolid $10 \mu \mathrm{g} / \mathrm{ml}$ (positive control) & 4 & $\mathrm{bc}$ \\
\hline Extract $150 \mathrm{mg} / \mathrm{ml}$ & 4 & $\mathrm{bc}$ \\
\hline Extract $200 \mathrm{mg} / \mathrm{ml}$ & 4 & $\mathrm{bc}$ \\
\hline Extract $50 \mathrm{mg} / \mathrm{ml}+$ linezolid $10 \mu \mathrm{g} / \mathrm{ml}$ & 4 & $\mathrm{~cd}$ \\
\hline Extract $100 \mathrm{mg} / \mathrm{ml}+$ linezolid $10 \mu \mathrm{g} / \mathrm{ml}$ & 4 & $\mathrm{~cd}$ \\
\hline Extract $150 \mathrm{mg} / \mathrm{ml}+$ linezolid $10 \mu \mathrm{g} / \mathrm{ml}$ & 4 & $\mathrm{~d}$ \\
\hline Extract $200 \mathrm{mg} / \mathrm{ml}+$ linezolid $10 \mu \mathrm{g} / \mathrm{ml}$ & 4 & $\mathrm{~d}$
\end{tabular}

Note: the same alphabet shows the same data between groups

\section{Discussion}

Antibiotics are still the main therapy for bacterial infections. However, overuse or inappropriate use of antibiotic contributes to the occurrence of resistance. Several studies to overcome these problems were mostly performed to improve the quality of life of the patients. Linezolid is one of new antibiotics that can be a solution to antibacterial resistance problem. Linezolid is the first bacteriostatic in the oxazolidinone group. Its target of action is to inhibit protein synthesis in the ribosome RNA 23S subunit 50S subunit. Linezolid is widely used to treat resistant Grampositive infections, such as MRSA or Vancomycin-Resistant Staphylococcus aureus (VRSA). ${ }^{16}$ These antibiotics have good potential in dealing with meningitis, endocarditis, and sepsis which are the complications of MRSA infection. ${ }^{17}$

Research on combinations of antibiotics and plant extracts, such as the coir extract of $C$. nucifera $L$. var rubescens, was also carried out. Our study demonstrates the synergy combination of coconut coir and linezolid could broaden the spectrum of antibacterial action. This shows a good therapeutic potential to overcome the problem of antibacterial resistance. ${ }^{7}$ Although the contents in coconut subspecies extracts, including coir extract of $C$. nucifera $L$. var rubescens, have not been specifically studied, a previous study found that $C$. nucifera coir itself contained phenol compounds. ${ }^{9}$ These compounds are secondary metabolites which are derivatives of the pentose pathway in plant metabolism. ${ }^{11}$ Phenol compounds can induce intracellular leakage that damages bacterial cell walls ${ }^{18}$ by inhibiting some of peptidoglycan structures, inhibit the growth of gram-positive bacteria, such as strain of S. aureus, ${ }^{7}$ and protects plant bodies against pathogens or predators. ${ }^{19}$

Inhibitory zone formation indicates the presence of antibacterial activity in the tested material. Our results showed an increase in extract concentration followed by an increase in mean diameter of the inhibitory zone formed. This is caused by the difference of antibacterial active substances level which directly proportional to the concentration of the extract. ${ }^{20}$ Diffusion of antibacterial active substances in the media, ${ }^{21}$ solvents used in the extraction process, ${ }^{22}$ as well as the sensitivity and size of bacterial inoculums, also influence the formation of inhibitory zone. ${ }^{23}$ The expansion of antibacterial action spectrum was shown by a larger mean diameter of the combination groups than the single groups. ${ }^{24}$ Other related studies also suggested a significant reduction in $S$. aureus MIC in the combination of plant extracts and antibiotics compared to the single use of the material. ${ }^{14}$ The combination of antibiotics and plant extracts can provide a synergistic, additive or antagonistic response. It is called synergistic if the combination gives a better response than the single use. ${ }^{25}$ The combination of antibacterial with different action targets shows a synergistic response. ${ }^{26}$ C. nucifera $L$. var rubescens coir extract is rich in phenol compounds, ${ }^{10}$ which can initiate intracellular leakage and inhibit the formation of peptidoglycan, ${ }^{27}$ along with linezolid which inhibits protein synthesis in the ribosome $23 \mathrm{~S}$ subunit 50S. ${ }^{16}$ The well-diffusion test method was selected by taking into account the limitations of the researchers in carrying out visual evaluation if dilution method were used.

\section{Conclusion}

C. nucifera $L$. var rubescens extract and its combination with linezolid have antibacterial activity against the growth of MRSA. The higher the concentration, the greater the mean inhibitory zone diameter. An increase mean diameter of inhibitory zone in combined group indicates higher antibacterial activity, so it is expected

\section{Conflict of Interest}

The author stated there is no conflict of interest

\section{References}

1. Stryjewski ME, Corey GR. Methicillin-resistant Staphylococcus aureus: An evolving pathogen. Clin Infect Dis. (SUPPL. 1). 2014;58

2. Choo EJ, Chambers HF. Treatment of methicillin-resistant Staphylococcus aureus bacteremia. Infect Chemother. 2016;48(4):267-73.

3. Chuang YY HY. Molecular Epidemiology of Community Associated Methicillin-Resistant Staphylococcus aureus in Asia. Lancet Infect Dis [Internet]. 2013; Available from: http://dx.doi.org/10.1016/ S1473-3099 (13)70136-1

4. World Health Organization (WHO). Antibiotic Resistance [Internet]. 2018. Available from: https:/www.who.int/news-room/fact-sheets/ detail/antibiotic-resistance

5. Kementrian Kesehatan Republik Indonesia. Mari Bersama Atasi Resistansi Antimikroba (Amr). 2016; Available from: http://www. depkes.go.id/article/view/16060800002/mari-bersama-atasiresistensi-antimikroba-amr-.html

6. Viju N, Satheesh S, Vincent SGP. Antibiofilm activity of coconut (Cocos nucifera Linn.) husk fibre extract. Saudi J Biol Sci [Internet]. 2013;20(1):85-91. Available from: http://dx.doi.org/10.1016/j. sjbs.2012.11.002

7. Akinyele TA, Igbinosa EO, Akinpelu DA, Okoh AI. In vitro assessment of the synergism between extracts of Cocos nucifera husk and some standard antibiotics. Asian Pac J Trop Biomed [Internet]. 2017;7(4):306-13. Available from: http://dx.doi.org/10.1016/j. apjtb.2016.12.022

8. Oliveira D, Martins GR, Jorge A, Alviano S, Nascimento RP, Auxiliadora $\mathrm{M}$, et al. Chemical and antimicrobial analysis of husk fiber aqueous extract from Cocos nucifera L. African J Biotechnol. 2013;12(18):2478-83.

9. Rodrigues S, Pinto GAS. Ultrasound extraction of phenolic compounds from coconut (Cocos nucifera) shell powder. J Food Eng. 2007;80(3):869-72.

10. Zhao W, Hu Z, Okubo S, Hara Y. Histology of Primary and Secondary Tumors y of Histology of Secondary Histology of Primary Tumor Secondary Embryonal / Yolk Sac Tumor. 2006;45(6):277.

11. Randhir R, Lin YT, Shetty K. Phenolics, their antioxidant and antimicrobial activity in dark germinated fenugreek sprouts in response to peptide and phytochemical elicitors. Asia Pac J Clin Nutr. 2004;13(3):295-307.

12. Piracha A. EDevelopment-assessment as "smart eplanning" for New South Wales (NSW) Australia. CUPUM 2015 - 14th International 
Conference on Computers in Urban Planning and Urban Management. 2015 .

13. L. Suhardiono. Tanaman Kelapa. Yogyakarta: Kanisius; 1993.

14. Adwan G, Mhanna M. Synergistic effects of plant extracts and antibiotics on Staphylococcus aureus strains isolated from clinical specimens. Middle-East J Sci Res. 2008;3(3):134-9.

15. Pankey G, Ashcraft D, Patel N. In vitro synergy of daptomycin plus rifampin against Enterococcus faecium resistant to both linezolid and vancomycin. Antimicrob Agents Chemother. 2005;49(12):5166-8.

16. Katzung \& Trevor's. Pharmacology Examination \& Board Review Eleventh Edition. 11th ed. 2015. 348-353 p.

17. Bozdogan B, Appelbaum PC. Oxazolidinones: Activity, mode of action, and mechanism of resistance. Int $\mathrm{J}$ Antimicrob Agents. 2004;23(2):113-9.

18. Skelley J. Open source tactics: Bargaining Power for strategic litigation. J Intellect Prop. 2016;16(1):1-35.

19. Bravo L. Polyphenols: Chemistry, Dietary Sources, Metabolism, and Nutritional Significance. Nutr Rev. 2009;56(11):317-33.

20. Jose M, Pai V, Shantaram M, Cyriac M. Antimicrobial properties of coconut husk aqueous extract on cariogenic bacteria. Arch Med Heal Sci. 2013;1(2):126.

21. Balouiri M, Sadiki M, Ibnsouda SK. Methods for in vitro evaluating antimicrobial activity: A review. J Pharm Anal [Internet].
2016;6(2):71-9. Available from: http://dx.doi.org/10.1016/j. jpha.2015.11.005

22. Ifah Hanik. Aktivitas Antibakteri Kombinasi Ekstrak Etanol Kulit Buah Delima (Punica granatum L.) dan Kloramfenikol Terhadap Staphylococcus aureus Sensitif dan Multiresisten Antibiotik. Universitas Muhammadiyah Surakarta; 2012.

23. Li J, Xie S, Ahmed S, Wang F, Gu Y, Zhang C, et al. Antimicrobial activity and resistance: Influencing factors. Front Pharmacol. 2017;8(JUN):1-11.

24. Ahmad I, Aqil F. In vitro efficacy of bioactive extracts of 15 medicinal plants against ES $\beta$ L-producing multidrug-resistant enteric bacteria. Microbiol Res. 2007;162(3):264-75.

25. Dwi Puspita Ayu. Aktivitas Antibakteri Kombinasi Ekstrak Etanol Daun Jambu Monyet (Anacardium Occidentale L.) dan Vankomisin Terhadap Staphylococcus aureus dan Staphylococcus epidermidis. Fakultas Farmasi Universitas Muhammadiyah Surakarta; 2013.

26. Chen C-S. Combinational Synergy of Antibiotics and Antimicrobial Peptides. J Transl Proteomics Res. 2017;3:6-11.

27. Alviano WS, Alviano DS, Diniz CG, Antoniolli AR, Alviano CS, Farias LM, et al. In vitro antioxidant potential of medicinal plant extracts and their activities against oral bacteria based on Brazilian folk medicine. Arch Oral Biol. 2008;53(6):545-52. 